\title{
Scholastic Aptitude Test, Sex and Department as Predictors of University Academic Performance: The Case of Addis Ababa University
}

Mohammed Gobeze*

Department of Psychology, Faculty of Social Science and Humanities, Oda Bultum University, Ethiopia

\begin{abstract}
The objective of the present study was to assess the predictive power of SAT, Sex and Department in AAU College of Science and Social Science. To analyse and interpret the collected data, both descriptive and inferential statistics were used. Pearson Product-Moment Correlation was employed to see the magnitude and direction of the relationship between the predictor variables and the criterion measure. To see the percentage of variance in students first year CGPA that can be explained by predictor variables multiple regression was used. Lastly, to identify relative contribution of predictor variables (or to identify the best predictor variable step-wise regression was employed. Predictor variables are statistically significant predictors of college academic performance for all participants $17.6 \%$ $\left(R^{2}=0.176, F(3,296)=21.068, P<0.05\right)$. Regarding the gender, there is a significant difference between male and female students college academic performance. A large amount of variance accounted for was found for female students $22 \%\left(R^{2}=0.220, F(2,95)=13.362, P<0.05\right)$ than for males $13.2 \%\left(R^{2}=0.132, F(2,199)=15.095, P<0.05\right)$. When the disciplines are considered, College of Science was found to be a more significantly predicted field of studies $17.5 \%\left(R^{2}=0.175, F(3,151)=10.697, P<0.05\right)$ than Social Science $8.4 \%\left(R^{2}=0.084, F(3,141)=4.317, P<0.05\right)$. Regarding the relative contribution of each predictor variables, the study result showed that department was the best predictor followed by SAT. Sex was a non-significant predictor of college CGPA. Hence, further investigation is required to conduct a study on the predictive power of sex.
\end{abstract}

Keywords: Predictive validity; Academic performance; Gender; AAU

\section{Introduction}

Almost always educators are concerned with decision making and prediction in education and psychology about learner's behaviour particularly an individual's learning ability. For this reason, they use test to help them in making prediction. Thus, either directly or indirectly aptitude tests as well as achievement tests are used to make predictions. But in this particular paper, the researcher deal with aptitude test particularly Scholastic Aptitude Test (SAT), Sex and Departments that were believed to be a useful in predicting academic success.

According to Ebel and Frisbie aptitude tests are used to predict how well an individual may learn and best able to predict future scholastic success. Similarly, Mehrens and Lehmann states aptitude tests as a measure of individual's ability to learn new tasks. Other authors Cronbach [1] also said that aptitude tests are constructed for the purpose of predicting student's future academic performance. By supporting the idea of Cronbach [1], recently reported that if the author's purpose is to develop a predictive instrument, he will no doubt call it an aptitude test.

Furthermore, the studies conducted in the past Ghiselli indicated that the correlations between aptitude test scores and success in college training programs tend to run between 0.40 and 0.50 . Since aptitude tests are most useful in predicting future school success, some authors have suggested that the phrase scholastic aptitude is the most honest and descriptive. The primary role of the aptitude test is to predict students' likely performance on a university course [2].

Little or no information on the predictive validity of SAT, Sex and Departments in a sufficient detail exist in our country. The present study, thus, was tried to investigate in a sufficient detail of the problem under investigation. Hence this attracts the interest of the researcher to conduct a study on the relationship of SAT, Sex and Departments with university academic performance within Addis Ababa university College of Social Sciences and Sciences [3].
Given the implications of existing research findings reviewed previously, the following research questions were formulated for the present study. More precisely, the purpose of this study was to assess the relationship between SAT, Sex, Departments and university academic performance. To this end, the following leading questions were formulated.

Is there a significant relationship between the predictor variables (SAT, Sex and Departments) and college academic performance? Is there a significant sex difference in college academic performance of first year students?

Is there any statistically significant difference in academic performance of students from College of Science and Social Science? What are the relative contributions of each predictor variables in predicting college academic performance?

\section{Methodology}

Correlation and regression method was employed to determine the degree and direction of relationship between the predictor variables and criterion measure. The target group of this study was batch of 2009/2010 academic year undergraduate degree entrants, College of Social Sciences and Sciences from AAU. They joined the college after passing EHEECE.

*Corresponding author: Mohammed Gobeze, Department of Psychology, Faculty of Social Science and Humanities, Oda Bultum University, Ethiopia, Tel +251910650372; E-mail: gobeze2003@gmail.com

Received November 07, 2017; Accepted November 14, 2017; Published November 21, 2017

Citation: Gobeze M (2017) Scholastic Aptitude Test, Sex and Department as Predictors of University Academic Performance: The Case of Addis Ababa University. Arts Social Sci J 8: 314. doi: 10.4172/2151-6200.1000314

Copyright: (c) 2017 Gobeze M. This is an open-access article distributed under the terms of the Creative Commons Attribution License, which permits unrestricted use, distribution, and reproduction in any medium, provided the original author and source are credited. 
Participants were 300 first year students enrolled to Addis Ababa University in the academic year 2009/2010. Of these participants 98 (32.7\%) and 202 (67.3\%) were females and males respectively [4-6]. The sample students were extracted from about 800 students in 13 departments of College of Science and Social Science. In this research paper the independent variables were the students' score of SAT, Sex and Departments. Similarly, the dependent variable was the students' university academic performance.

To analyse and interpret the collected data, both descriptive and inferential statistics were used [7-10]. Pearson Product-Moment Correlation was employed to see the magnitude and direction of the relationship between the predictor variables and the criterion measure. To see the percentage of variance in students first year CGPA that can be explained by predictor variables multiple regression was used. Lastly, to identify relative contribution of predictor variables (or to identify the best predictor variable step-wise regression was employed).

\section{Results and Discussion}

\section{Descriptive statistical results}

To show the general feature of predictor variables (SAT, Sex and Department) and criterion (university academic performance) variable, descriptive statistics are used. With reference to the statistical results, descriptive measures that involve means and standard deviation of independent and a dependent variable. For the total group and each sub-group based on the categories made by department, and sex of first year students have been presented in Table 1.

Upon entering the university, the entire study participants in the sample had a mean age of 18.61 with a standard deviation of 3.781. The mean of aptitude test score was 55.92 with a standard deviation of 13.034. As can be seen from the above table, at departmental level, the mean and standard deviation of SAT varied from 46.78 to 63.89 and from 8.383 to15.595, respectively. On the other hand, regarding the gender, we can understand from this table that the mean and standard deviation of aptitude test scores were varied for sex. The result in this table indicates that many male students on average were scored higher on aptitude test $[11,12]$. And the standard deviation indicates that there is sufficient variation in a female aptitude test scores compared to male. But in the case of criterion measure considerable variations were obtained for male students compared to female students.

Concerning the criterion measure, the mean CGPA achieved in first year is 2.65 for the total participants with a standard deviation of 0.467 and varied from 2.39 to 2.97 and from 0.237 to 0.572 respectively at departmental level. Particularly students who enrolled in college of Social Science on average have higher mean CGPA of 2.77 when compared to those of Science participants who had mean CGPA of 2.53. More specifically, from this descriptive statistics, one can understand

\begin{tabular}{|c|c|c|c|c|c|c|c|}
\hline & \multicolumn{5}{|c|}{ Statistics } & \multicolumn{2}{|c|}{ Age } \\
\hline & Mean SAT & St.dev & Mean CGPA & St.dev & $\mathbf{N}$ & Mean & Std.dev \\
\hline \multicolumn{6}{|l|}{ SAT } & & \\
\hline Total & 55.92 & 13.034 & ----- & ----- & 300 & & \\
\hline Male & 58.37 & 11.833 & ----- & ---- & 202 & & \\
\hline Female & 50.88 & 13.977 & ------ & ----- & 98 & & \\
\hline \multicolumn{6}{|l|}{ SEX } & & \\
\hline Total & ---- & ---- & 2.65 & 0.467 & 300 & & \\
\hline Male & ----- & ---- & 2.7 & 0.472 & 202 & & \\
\hline Female & ----- & ----- & 2.54 & 0.44 & 98 & & \\
\hline \multicolumn{6}{|l|}{$\begin{array}{l}\text { Department } \\
300\end{array}$} & & \\
\hline Science & 57.98 & 13.793 & 2.53 & 0.403 & 155 & 18.61 & 3.781 \\
\hline Mathematics & 63.89 & 11.318 & 2.39 & 0.237 & 27 & & \\
\hline Physics & 63.87 & 8.383 & 2.47 & 0.522 & 15 & & \\
\hline Biology & 56.76 & 12.44 & 2.55 & 0.407 & 37 & & \\
\hline Chemistry & 52.92 & 15.595 & 2.45 & 0.437 & 26 & & \\
\hline Statistics & 62.33 & 12.714 & 2.67 & 0.411 & 16 & & \\
\hline Earth Science & 53.31 & 15.414 & 2.64 & 0.407 & 32 & & \\
\hline Social Science & 53.72 & 11.824 & 2.77 & 0.497 & 145 & & \\
\hline Geography & 51 & 12.546 & 2.72 & 0.425 & 24 & & \\
\hline History & 57.18 & 13.001 & 2.71 & 0.433 & 17 & & \\
\hline Sociology & 58.24 & 11.569 & 2.77 & 0.516 & 29 & & \\
\hline Anthropology & 51.41 & 10.773 & 2.87 & 0.508 & 22 & & \\
\hline PSIR & 55.42 & 10.885 & 2.97 & 0.54 & 26 & & \\
\hline Philosophy & 46.78 & 9.944 & 2.51 & 0.421 & 18 & & \\
\hline Archeology & 54.44 & 10.841 & 2.77 & 0.572 & 9 & & \\
\hline \multicolumn{6}{|l|}{ CGPA } & & \\
\hline Total & ---- & ----- & 2.65 & 0.467 & 300 & & \\
\hline Male & ---- & ---- & 2.7 & 0.472 & 202 & & \\
\hline Female & ---- & ----- & 2.54 & 0.44 & 98 & & \\
\hline
\end{tabular}

Note: Values are for all participants.

$\mathrm{N}=300$.

SAT: Scholastic Aptitude Test; CGPA: Cumulative Grade Point Average.

Table 1: Mean and standard deviation of the variables in the study(for total participants $(N=300)$. 
that the mean value of CGPA across the department indicates that on average the entire study participants were medium in their university academic performance [13-16]. The standard deviation values on the other hand indicate that there is a considerable variation in CGPA particularly in the department of Archaeology, PSIR, Sociology and Social Anthropology among others $[17,18]$. Whereas in the department of Mathematics and Biology the variation of CGPA were found to be modest compared to the other departments among college of Science and Social Science.

Analysing the characteristics of the distribution of variables considered in the study, the degree of variability within CGPA is smaller in the criterion measure than the dispersion of predictor variables (SAT, Sex and Departments) across the participants. This means that the standard deviation found for CGPA is smaller than the standard deviation of the independent variables. One can understand from this that the range of restriction is seen highly in the criterion measure (CGPA) than the predictor variables.

\section{Correlation analysis}

From the inter correlation matrix displayed in Table 2, we can understand that all the considered predictor variables are related positively with each other except for Department $\left(\mathrm{X}_{3}\right)$ which was negatively related with $\mathrm{SAT}\left(\mathrm{X}_{1}\right)$. All the relationships between the predictor variables are statistically significant (at $\mathrm{P}<0.01)$.

While conducting these analyses, multi co-linearity was diagnosed between predictor variables in the present study (SAT, Sex and Department) (Table 2). "If two independent variables are correlated at level greater than $r=0.70$, some authors Zizzi, cited in Aboma suggest removing one of the variables from multiple regression analysis." However, in our case, there was no such problem of co-linearity among the predictor variables (Table 2).

\begin{tabular}{|l|l|l|l|l|}
\hline Variables & SAT & Sex & Department & CGPA \\
\hline Sat & 1 & & & \\
\hline Sex & $0.270^{\star *}$ & 1 & & \\
\hline Department & $-196^{\star *}$ & $.193^{\star *}$ & 1 & \\
\hline CGPA & $0.218^{\star *}$ & $.156^{\star *}$ & $.308^{\star *}$ & \\
\hline
\end{tabular}

Values are for all participants.

${ }^{* *} \mathrm{P}<0.01$, 2-tailed.

SAT: Scholastic Aptitude Test; CGPA: Cumulative Grade Point Average.

Table 2: Inter correlation matrix between the predictor variables and the criterion variable.
Pearson correlation indicates that the relationship between the predictor variables and university academic performance are statistically significant (at $\mathrm{P}<0.01$ and $\mathrm{N}=300$ ). From this inter correlation matrix, we can understand that all the considered variables in the present study are related positively with university academic performance. Though all the relationships are statistically significant, Departments $\left(\mathrm{X}_{3}\right)$ is highly related with first year CGPA(Y) followed by SAT test scores $\left(\mathrm{X}_{1}\right)$ and Sex $\left(\mathrm{X}_{2}\right)$ was the least correlated predictor variable with CGPA compared to the other two variables(SAT and Department). From the results depicted in Table 2, one can understand that the correlation of SAT and Department with CGPA were medium $(r=.218)$ and $(r=.308)$ respectively [19-21].

\section{Multiple regression analysis}

Regression Equation, $\mathrm{Y}^{\prime}=0.287 \mathrm{X}_{1}+0.008 \mathrm{X}_{2}+0.363 \mathrm{X}_{3}+1.706$

Where, $\mathrm{X}_{1}=$ Scholastic Aptitude Test

$\mathrm{X}_{2}=$ Sex, Sex is dummy coded, Male $=1$, Female $=0$

$\mathrm{X}_{3}=$ Department, all Departments are categorized into Science and Social Science for our purpose, then dummy coded, in this case, College of Science $=20$, College of Social Science $=40$. One can understand from the multiple regression result displayed in the above table, SAT and Department were the only significant predictors of university academic performance. The result of multiple regression analysis also showed the use of SAT, Sex and Department in combination to predict the entire study participants' CGPA accounted for $17.6 \%\left(\mathrm{R}^{2}=0.176\right.$, $\mathrm{F}(3,296)=21.068, \mathrm{P}<0.05)$ of the total variance in students' first year CGPA. In the model, only SAT and Department were the significant predictors of college academic performance ( $B=.363$ for Department) and $(B=.287$ for SAT). However, sex was failed to be a significant predictor of college CGPA.

When the sex is considered, a large amount of variance accounted for was found for female students $22 \%\left(R^{2}=0.220, F(2,95)=13.362\right.$, $\mathrm{P}<0.05)$ than for male students $13.2 \%\left(\mathrm{R}^{2}=0.132, \mathrm{~F}(2,199)=15.095\right.$, $\mathrm{P}<0.05)$. Predictor variables explained more of the variance in college CGPA for females than for male students. More specifically the study result indicated that the variance in females' first year CGPA accounted for by SAT and Department $12.9 \%$ and $9.1 \%$, respectively (Table 3). On the other hand, the variance in males' first year CGPA that accounted for by SAT and Department were found to be $5.3 \%$ and $7.9 \%$, respectively. From these findings, one can easily understand that the correlation between aptitude test and first year CGPA were

\begin{tabular}{|c|c|c|c|c|c|c|c|c|}
\hline St. group & $\mathbf{N}$ & Predictors & b & B & $\mathbf{t}$ & $\mathbf{R}$ & $\mathbf{R}^{2}$ & F-ratio \\
\hline \multirow[t]{4}{*}{ All } & \multirow[t]{4}{*}{300} & Constant & 1.706 & & 12.893 & & & \\
\hline & & SAT & .010 & .287 & $5.057^{*}$ & & & \\
\hline & & Sex & .008 & .008 & .140 & .419 & .176 & $21.068^{*}$ \\
\hline & & Department & .048 & .363 & $6.519^{*}$ & & & \\
\hline \multirow[t]{4}{*}{ Male } & \multirow[t]{4}{*}{202} & Constant & 1.793 & & 9.369 & & & \\
\hline & & SAT & .009 & .236 & $3.466^{*}$ & & & \\
\hline & & Sex & .004 & .005 & .676 & 3.63 & .132 & 15.096* \\
\hline & & Department & .044 & .338 & $4.973^{*}$ & & & \\
\hline \multirow[t]{4}{*}{ Female } & \multirow[t]{4}{*}{98} & Constant & 1.561 & & 7.756 & & & \\
\hline & & SAT & .012 & .378 & $3.958^{*}$ & & & \\
\hline & & Sex & .003 & .002 & .334 & .469 & .220 & $13.362^{*}$ \\
\hline & & Department & .067 & .420 & $4.399^{*}$ & & & \\
\hline
\end{tabular}

Values are for all participants.

${ }^{*} \mathrm{P}<0.05$.

SAT: Scholastic Aptitude Test..

Table 3: Multiple Regression Analysis of predicting college academic performance by using SAT, Sex and Department. 


\begin{tabular}{|c|c|c|c|c|c|c|c|}
\hline Stud Group & $\mathbf{N}$ & Model & Predictors & $\mathbf{R}$ & $\mathbf{R}^{2}$ & Adj. $\mathbf{R}^{2}$ & F-Ratio \\
\hline \multirow[t]{2}{*}{ All } & \multirow[t]{2}{*}{300} & 1 & Department & .308 & .095 & .092 & $31.342^{*}$ \\
\hline & & 2 & $\begin{array}{l}\text { Department } \\
\text { SAT }\end{array}$ & .419 & .176 & .170 & $31.696^{*}$ \\
\hline \multirow[t]{2}{*}{ Male } & \multirow[t]{2}{*}{202} & 1 & Department & .282 & .079 & .075 & $17.229^{*}$ \\
\hline & & 2 & $\begin{array}{l}\text { Department } \\
\text { SAT }\end{array}$ & .363 & .132 & .123 & $15.095^{*}$ \\
\hline \multirow[t]{2}{*}{ Female } & \multirow[t]{2}{*}{98} & 1 & Department & .301 & .091 & .081 & $9.592^{*}$ \\
\hline & & 2 & $\begin{array}{l}\text { Department } \\
\text { SAT }\end{array}$ & .469 & .220 & .203 & $13.362^{*}$ \\
\hline
\end{tabular}

Values are for all participants.

${ }^{*} \mathrm{P}<.05$.

SAT $=$ Scholastic Aptitude Test.

Table 4: Final Summary of Step-Wise Multiple Regression of predicting college academic performance from SAT and Department.

higher for females than for males [22,23]. Generally this implies that the model in the present study was stronger for predicting first year students CGPA for females than for males. This finding was consistent with the previous findings. For instance, Mattern et al [3] reviewed the literature on differential validity and prediction by gender which comprised 48 validity studies and prediction studies, arrived at similar conclusions [24]. Accordingly the predictive validity for college success almost always higher for females than males.

\section{Step-wise multiple regression analysis}

As can be seen from the above Table 4, stepwise multiple regression analysis revealed that Department $(\mathrm{B}=.308, \mathrm{P}<0.05)$ was the most important predictor of first year college academic performance followed by SAT scores $(\mathrm{B}=0.111, \mathrm{P}<0.05)$ for all participants [25-27]. The variance accounted for by Department was $9.2 \%\left(\mathrm{AdjR}^{2}=.092\right.$, $\mathrm{F}(1,198)=31.342, \mathrm{P}<0.05)$ and the combination of Department and SAT on model two accounted $17 \%\left(\operatorname{Adj}^{2}=0.170, F(2,197)=31.696\right.$, $\mathrm{P}<.05$ ). From the above value in the combination of Department and SAT on model two, $7.8 \%$ (AdjR ${ }^{2}=0.078$ ) was accounted for by SAT alone. The findings of this study indicated that both Department and SAT scores were significant predictors of college CGPA. These results were consistent across the gender. Accordingly, Department explained 8.1\% (AdjR $\left.\mathrm{R}^{2}=0.081, \mathrm{~F}(1,96)=9.592, \mathrm{P}<0.05\right)$ and the combination of Department and SAT 20.3\% $\left(\operatorname{AdjR}^{2}=.203, \mathrm{~F}(2,95) 13.362, \mathrm{P}<.05\right)$ for females than Department 7.5\% $\left(\operatorname{AdjR}^{2}=.075, \mathrm{~F}(1,200)=17.229, \mathrm{P}<.05\right)$ and the combination of Department and SAT on model two $12.3 \%$ $\left(\operatorname{Adj}^{2}=0.123, \mathrm{~F}(1,199)=15.095, \mathrm{P}<.05\right)$ for males. However, in the present study, Sex was failed to be a significant predictor of college CGPA.

\section{Discussion}

In the present study, aptitude test, Sex and Department were used as predictor variables of university academic performance. The major findings of this study will be discussed in the light of the research questions raised in the introductory part of the study.

As to the predictive power of SAT, Sex and Department, the results indicate that there is statistically a significant relationship between the predictor variables and criterion measure $17.6 \%\left(\mathrm{R}^{2}=1.176, \mathrm{~F}(3\right.$, $296)=21.068, P<.05$ ). Particularly SAT and Department were found to be a significant predictors of college academic performance.

The findings concerning sex difference in college academic performance, gender difference was observed in the present study. Predictor variables explained more of the variance in college CGPA for female students than for male students $[28,29]$. This implies that the model was stronger for predicting first year CGPA for female than foe males. These findings are in agreement with that of Bridgeman, Mc Camley and Ervin cited in Young et al. According to these authors the differential validity results showed that females college CGPA was more predicted by aptitude test than those of males.

Whenever the disciplines categorized as College of Science and Social Science, College of Science as a whole were found to be a more significantly predicated field of studies by aptitude test and Department. These findings confirm the previous findings. For example, according to Pearson although prediction of college academic performance by aptitude test across all disciplines is modest, there was a wide variation at department level. A finding by this author shows that prediction of Sciences to be generally more accurate than of Social Sciences.

Concerning with identifying the relative contribution of each predictor variables, as can be understand from the present study, step-wise multiple regression analysis revealed that Department $(\mathrm{B}=.308, \mathrm{P}<0.05)$ was the most important predictor of first year college academic performance followed by SAT scores $(\mathrm{B}=0.111, \mathrm{P}<0.05)$ for all participants. The variance accounted for by Department was $9.2 \%$ $\left(\operatorname{Adj}^{2}=0.092, \mathrm{~F}(1,198)=31.342, \mathrm{P}<0.05\right)$ and the combination of Department and SAT on model two accounted $17 \%\left(\operatorname{Adj}^{2}=0.170, \mathrm{~F}\right.$ $(2,197)=31.696, \mathrm{P}<0.05)$. From the above value in the combination of Department and SAT on model two, $7.8 \%\left(\mathrm{AdjR}^{2}=0.078\right)$ was accounted for by SAT alone [30,31].

\section{Conclusion}

The results of the predictive power of SAT, Sex and Departments are observed in the previous chapter. The following conclusions are made on the basis of the findings.

1. There is a significant relationship between aptitude test, Sex, Department and first year college academic performance as measured by CGPA.

2. There is a significant Sex difference in college academic performance. Females' first year CGPA were found to be more predicted than those of male students.

3. There is a significant difference between the Science and Social Science departments' CGPA prediction. Accordingly, College of Science was more predicted in the model than those of Social Sciences.

4. Department was the best predictor of college CGPA followed by SAT. However, sex was found to be a non-significant predictor of college academic performance.

Generally, the findings of this study reveal that males and Science 
Citation: Gobeze M (2017) Scholastic Aptitude Test, Sex and Department as Predictors of University Academic Performance: The Case of Addis Ababa University. Arts Social Sci J 8: 314. doi: 10.4172/2151-6200.1000314

Page 5 of 5

students' college academic performance on average are over-estimated while females and Social Science students are under-estimated particularly when aptitude test is used to predict college CGPA.

\section{References}

1. Cronbach LJ (1970) Essentials of Psychological Testing. Harper and Row Publishers, New York, USA.

2. McDonald A, Newton $P$, Whetton C, Benefield $P$ (2010) Aptitude Testing for University Entrance: A Literature Review.

3. Kobrin LJ, Patterson FB, Shaw JE, Mattern DK, Barbuti MS, et al. (2008) Validity of the SAT for Predicting First-Year College Grade Point Average.

4. Aleamoni LM, Oboler L (1978) ACT Versus SAT in Predicting First Semester GPA. Educ Psychol Meas 38: 393-399.

5. Kumilachaw A (2007) Predictive Validity of the Ethiopian Higher Education Entrance Certificate Examination. Unpublished M.A. Thesis, Addis Ababa University, Ethiopia.

6. Anastasi A (1976). Psychological Testing. (4thedn), Macmillan Publishing Co. Inc, New York, USA.

7. Arbona C, Novy DM (1990) Non- Cognitive Dimensions as Predictors of College Success. J Coll Stud Dev 31: 415-422.

8. Worthen BR, Spandel V (1991) Putting the Standardized Test Debate in Prespective. Educ Leadersh 48: 65-69.

9. Bron FG (1983) Principle of Educational and Psychological Testing., CBS College Publishing, New York, USA.

10. Burton NW, Ramist L (2001) Predicting Success in College: SAT Studies of Classes Graduating Since 1980. College Entrance Examination Board, New York, US.

11. Deptula EJ (1984) ARCO Preparation for the SAT, Scholastic Aptitude Test Acro Publishing, New York, USA.

12. Edward JD (1984) ARCO Preparation for the SAT Scholastic Aptitude Tes New York. Acro Publishing a division of Simon and Schuster Inc.

13. Fincher C (1974) Is SAT worth it Salt? Aptitude Test in the University System of Georgia Over a thirteen Year Period. Review of Educational Research 44 293-305.

14. Gilbert R Austin, Herbert Garber (1982) The Rise and Fall of National Test scores. Center for Educational Research and Development University of Maryland. Academic Press Inc.

15. Gronlund NE (1985) Measurement and Evaluation in Teaching New York McMillan Publishing Company.

16. Harrison GG (1968) Predicting Performance in Student Teaching from the
California Psychological Inventory. Journal of Educational Psychology 59: 119127.

17. Koul, Lokesh (1988) Methodology of Educational Research Delhi: Vikas Publishing PVT Ltd.

18. Kruck SE, Lending D (2003) Predicting Academic Performance in an Introductory College-level is Course IT, Learning, and Performance Journal 21 : 9-12.

19. Luck (2007) How Accurate are the SAT and ACT in Predicting Future Performance in College.

20. Lungmuri, C, Bowers J (1967) The Prediction of Freshman Success at Haile Sillasie I University With the Special Scholastic Aptitude Test. Addis Ababa University.

21. Meherens WA, Lehmann IJ (1972) Standardized Tests in Education. New York Holt, Rinehart and Winston, Inc.

22. Mehrens WA, Lehmann IJ (1984). Measurement and Evaluation in Education and Psychology (3rd ed.) Halt, Rinahort and Winston. New York

23. Meresa Abraha (1994) Predictive validity of Admission Criteria used by the Ethiopian Electric Light and Power Institutes" Unpublished Masters Thesis, AAU.

24. Nitko AJ (1983) Educational Tests and Measurement: An Introduction. New York: Harcourt Brace Jovanovich, Inc, pp: 623-649.

25. Peassons WR (1967) Predictive Validities of the SAT, ACT and High Schoo Grades for First Semester GPA and Freshman Courses. Educational and Psychological Measurement, pp: 1143-1144.

26. Ronald Jay, Cohen (2002) An Introduction to Tests and Measurement. The McGraw-Hill Companies, Inc.

27. Rothstein MJ (2003) College Performance Predictions and the SAT. Journal of Econometrics 121: 297-317.

28. Saul G, Maria veronica S (2007) Validity of high School Grades in Predicting Student Success Beyond The Freshman Year: High- School Record Vs. Standardized Tests as Indicators of Four- Year College Outcomes. Research \& Occasional Paper Series.

29. Wayne JC, Gary E (2000) The SAT and High School Grades: Utility in Predicting Success in College.

30. Whetton C, Kirkup C, Schagn I, Wheater R, Morrison J (2007) Preliminary Stages of a Validity Study of the Use of an Aptitude Test in University Entrance. Paper Presented at the 33rd International Association for Educational Assessment Conference.

31. Wosen W (2007) High School Average Scores, EGSECE GPA, and Entrance Exam Result as Predictors of CollegePerformance. 